\title{
A Review of Team-Focused Transformational Leadership: Past and New Trends
}

\author{
Lihong Lai \\ School of Management, Jinan University, Guangzhou, China \\ Email:977563881@qq.com
}

How to cite this paper: Lai, L.H. (2019) A Review of Team-Focused Transformational Leadership: Past and New Trends. Journal of Service Science and Management, 12, 172-185.

https://doi.org/10.4236/jssm.2019.122012

Received: January 24, 2019

Accepted: February 22, 2019

Published: February 25, 2019

Copyright $\odot 2019$ by author(s) and Scientific Research Publishing Inc. This work is licensed under the Creative Commons Attribution International License (CC BY 4.0).

http://creativecommons.org/licenses/by/4.0/

c) (i) Open Access

\begin{abstract}
Based on the new development of the transformational leadership theory, namely differentiated transformational leadership, this paper sorts out the related concepts, structures and measurements of individual-focused transformational leadership and team-focused transformational leadership. Based on contingent leadership theory, individual-focused transformational leadership focuses on individual employees and has different leadership styles for different subordinates. Team-focused transformational leadership pays more attention to the overall team, attaches importance to team goals and team interests, and consolidates the power of subordinates to achieve team goals through emphasizing the common background and values of the team. In a collectivist society, the team-focused transformational leadership is more in line with the Chinese situation. The last part elaborates the mechanism of the team-focused transformational leadership on team creativity. Most studies believe that team-focused transformational leadership can build the atmosphere of team trust and cooperation. Subordinates are happy at work, then their motivation is stronger, which is conducive to the realization of the team goal, that is, the team-focused transformational leadership can positively influence the team creativity.
\end{abstract}

\section{Keywords}

Differentiated Transformational Leadership, Individual-Focused

Transformational Leadership, Team-Focused Transformational Leadership

\section{Definition of Transformational Leadership}

After the leadership traits, leadership behavior theory and leadership contingency theory, the concept of transformational leadership was first proposed by Burns in his classic book "Leadership" during 1980s. It believed that transforma- 
tional leadership mainly enhances the maturity and motivation level of each other through interaction between leaders and subordinates. It was defined as "leaders seek and inspire subordinates' potential power through high-level ideas and values, prompt subordinates to be fully immersed in the work and establish mutual encouragement and promotion relationship between leaders and subordinates". Bass (1985) continues to expand the concept of transformational leadership and believes that transformational leadership is to "make subordinates aware of the meaning and importance of tasks, motivate and meet their high-level needs and build a climate of mutual trust. In turn, the subordinates place the collective interests ahead of individual interests and produce more than expected work results" [1]. Based on Burns and Bass' definition of transformational leadership, scholars began to define the concept of transformational leadership from different perspective.

It can be seen from Table 1 that although scholars have different definitions of transformational leadership, scholars' views are basically the same in terms of the substantive content of transformational leadership characteristics. By comparison, it is found that scholars' definition of transformational leadership includes the following basic characteristics:

1) Transformational leadership instills organizational vision to organizational members, clarifies the meaning of the work and encourages team members immerse in work to realize organize goals.

2) Transformational leadership should play the role of model, establish a good atmosphere of mutual trust and respect in the team, stimulate the intrinsic motivation of team members, and make team members willing to follow the leadership and sacrifice personal interests for organizational interests.

3) Transformational leadership concerned subordinates self-realization, stimulates their enthusiasm and confidence to promote organizational development and goal realization.

In short, transformational leadership is able to grasp organizational goals and depict the blueprint clearly for future organizational development to team members through vision incentives. As a role model, transformational leadership builds respect and trust between leaders and subordinates, incentives team members into work through stimulate the intrinsic motivation of team members. Transformational leaders focus on the self-fulfilling needs of team members, inspiring subordinates to struggle to organizational goals beyond self-interest.

\section{The Difference and Connection between Transformational Leadership and Other Types of Leadership}

Based on the theory "hierarchy of needs", transformational leadership refers to the establishment of a climate of mutual trust by inspiring the high-level needs of subordinates, and prompting subordinates to sacrifice their own interests for the benefit of the organization, ultimately achieve organizational goals. On the 
Table 1. Definition of transformational leadership.

\begin{tabular}{|c|c|}
\hline Source of literature & Definition \\
\hline Burns (1978) & $\begin{array}{l}\text { Leaders motivate subordinates to work hard, and promote } \\
\text { subordinates and reform through higher-level values encouragement. }\end{array}$ \\
\hline Bass (1985) & $\begin{array}{l}\text { The leader explains the importance of the task to subordinates, Inspire } \\
\text { the intrinsic motivation of subordinates, realize the importance of } \\
\text { collective interests and expect their higher performance. }\end{array}$ \\
\hline Yukl (1989) & $\begin{array}{l}\text { Leaders strengthen their sense of mission to the organization by } \\
\text { affecting the attitudes and behaviors of the members, allow the } \\
\text { subordinates do their work willingly, match management strategies to } \\
\text { organizational culture to ensure the achievement of organizational goals. }\end{array}$ \\
\hline Leithwood (1992) & $\begin{array}{l}\text { Leaders demonstrate the organizational vision and encourage } \\
\text { subordinates' enthusiasm and commitment to their work, } \\
\text { make subordinates hopeful about the future and achieve } \\
\text { organizational goals through practical actions. }\end{array}$ \\
\hline Pillai et al. (1999) & $\begin{array}{l}\text { By inspire the inner needs of subordinates, the leaders enable } \\
\text { subordinates to build the interests of organization over their } \\
\text { own interests and build a mutual trust working atmosphere, } \\
\text { thus prompt subordinates higher performance. }\end{array}$ \\
\hline Robbins (2001) & $\begin{array}{l}\text { Through intrinsic motivation and care, the leader makes the } \\
\text { subordinates willing to pay for the organization and inspire } \\
\text { subordinates to make efforts even sacrifices of the interests } \\
\text { of the organization to accomplish organizational goals } \\
\text { through their personal traits. }\end{array}$ \\
\hline $\begin{array}{l}\text { Waldman et al. } \\
\qquad(2001)\end{array}$ & $\begin{array}{l}\text { Transformational leaders attempt to establish a friendly relationship } \\
\text { with subordinates. Leaders describe the organization's vision and } \\
\text { expectations for high performance, so that subordinates enhance } \\
\text { their respect of leaders and confidence in work and demonstrate } \\
\text { the determination to work hard and the sense of mission } \\
\text { to achieve organizational goals. }\end{array}$ \\
\hline Ackoff (2007) & $\begin{array}{l}\text { Transformational leaders describe organizational vision with } \\
\text { subordinates, so that subordinates feel that they can achieve their } \\
\text { organizational vision through their own efforts, they are willing to } \\
\text { sacrifice personal interests for the benefit of the organization. By } \\
\text { creating an organizational atmosphere, subordinates can feel happy at } \\
\text { work and have a sense of self-realization. Ultimately, leaders are } \\
\text { sure to promote team members to achieve organizational goals. }\end{array}$ \\
\hline $\begin{array}{l}\text { Li, C.P. and Shi, K. } \\
\text { (2005) }\end{array}$ & $\begin{array}{l}\text { Transformational leaders portray the organizational vision to } \\
\text { subordinates, awaken the intrinsic motivation of subordinates and } \\
\text { motivate employees to self-realization, transcend "ordinary self" to } \\
\text { achieve "more self", strive to increase work commitment } \\
\text { and ultimately achieve organizational goals. }\end{array}$ \\
\hline
\end{tabular}

basis of the six dimensions of Bass et al. (1985) [1]. Avolio \& Bass (1999) divide transformational leadership into four dimensions: inspirational motivation, idealized influence, individualized consideration, and intellectual stimulation. Idealized influence refers to the behaviors that enable others to generate trust, worship, and follow. Includes win identity, respect and trust of the subordinate, these leaders generally have recognized high ethical standards and personal charisma, they are deeply loved and trusted by their subordinates. Inspirational mo- 
tivations point to leader elaborate a very attractive vision and inspire subordinates to work towards a common vision. Intelligence stimulation means encourage subordinates to innovate and challenge themselves, including instill new ideas into subordinates, inspire subordinates to express new opinions and encourage them to solve problems encountered in their work with new methods. Individualized consideration means concerned the needs of each subordinate as well as their abilities and aspirations, be patient and meticulous listening, training and guidance each subordinate according to the different situations and the needs of each subordinate [2]. Transactional leadership refers to satisfy the interest relationship between leaders and employees. Leaders clarify the needs of employees and negotiate with employees to set goals, stimulate employees through positive or negative behaviors [3]. Based on stakeholder theory, responsible leadership refers to leaders establish, foster and maintain mutual trust relationship with stakeholders and work together to achieve a shared business vision. Public servant leadership is a leadership behavior that transcends the individual interests of the leader, the leadership respects the dignity and value of the followers and serves others as the first priority to meet the physical, psychological and emotional needs of the followers [4]. Intellectual leadership is a leadership behavior based on social learning theory, intellectual leadership creates a learning atmosphere in the organization, as role models, encourages team members to continue learning and give supports to team members [3]. Entrepreneurial Leadership refers to the leadership create a vision, call for and mobilize subordinates to explore and discover strategic values [5].

Among these leaders, transactional leadership is based on the exchange of interests between leaders and members to achieve team management. Responsible leadership based on the relationship management between stakeholders to achieve the organization's business strategic intentions. Public servant leaders focus on subordinate ethics and service motivation and emphasize the leadership's dedication to the subordinates' cultivation process. Knowledge-based leadership emphasizes Learning within the organization and supports team members' learning to meet organizational development. As an exploratory leadership, entrepreneurial leadership aimed at how to lead team members to meet uncertain challenges in uncertain environment. Different from the front, transformational leadership focuses on the development of employees and team building simultaneously, transformational leadership able to lead team members to achieve unexpected organizational goals in a fiercely competitive environment. Besides, many researches have found that transformational leadership is the key to deal with external competition as well as effective management of the team.

\section{Connotation of Team-Focused Transformational Leadership and Individual-Focused Transformational Leadership}

Van Knippenberg (2013) pointed out that previous research on the concept of transformational leadership is unclear. Many studies have found that transfor- 
mational leadership can be divided into individual level and teams level [6]. Based on the relative maturity of transformational leadership theory, Kark and Shamir (2002) incorporate self-concept into the research of transformational leadership, propose team-focused and individual-focused transformational leadership concept, they believe that transformational leadership have different effect on subordinate individuals and teams [7].

Team-focused transformational leadership emphasizes the common background and shared values among team members, motivates members to accept team goals by articulate a compelling vision clearly or play a role model in the team [8]. Team-focused transformational leadership regards the team as a whole, values team goals and common interests of the team [9]. Team-focused transformational leadership awakens members' recognition of the team and motivates members to work hard for the team's common goals [10]. Team-focused transformational leadership pay more attention to the team as a whole, team members tend to form a relatively consistent perception of leaders [11], and then these subordinates express similar emotions, attitudes, and behaviors. It is worth noting that team-focused transformational leadership does not mean that a series of behaviors only occur at the level assigned, but conceptually, some behaviors are more conceptually functional and more likely to occur at a particular level [12].

Different transformational leadership behaviors will stimulate subordinates' different self-concepts, which in turn leads to different subordinate behaviors [13]. Individual focused transformational leadership refers to leadership that emphasizes the uniqueness of individual members by pay close attention to individual needs and development, what's more, inspire them intellectually. Based on contingency leadership theory, Individual-focused transformational leadership concerned individual members rather than the whole team, leaders behave different when face different subordinates in different contextual factors, which involve members of the team have inconsistent perceptions of individual-focused transformational leadership behaviors [14]. In addition, the leader will adopt different guidance according to different characteristics of the team members, set different working goals for different subordinates [7]. They play leadership effectiveness through the cognition of different subordinates according their own factors (such as traits and abilities, etc.) or situational factors (e.g., team atmosphere and job characteristics, etc.) [9].

\section{The Structure and Measurement of Individual-Focused and Team-Focused Transformational Leadership}

The measurement of multi-level transformational leadership comes from the researches, such as Bass (1985) and Podaskoff et al. (1990), and under the basis of original transformational leadership, we classified and analyzed the dimension and measurement of transformational leadership.

Bass (1985) first proposed the concept of transformational leadership, and es- 
tablished the MLQ (Multifactor Leadership Questionnaire) scale for measuring transformational leadership, which includes four dimensions, Inspirational Motivation, Individualized Consideration, Intellectual Stimulation and Charisma [1]. With the research of scholars, it is found that there are different levels of in the tradition four dimensions of the transformational leadership. Kark and Shamir (2002) classify the structural dimensions of the MLQ scale and divide the transformational leadership behavior into different levels. They think that among the four dimensions, the two dimensions of individualized consideration and intellectual stimulation should be classified as individual-focused transformational leadership, and the two dimensions of charisma and inspiration motivation should be classified as team-focused transformational leadership [7]. However, Kark and the others simply performed a simple division based on the MLQ scale, and they did not test the validity of such classification, nor did they re-develop the multilevel transformational leadership scale. Therefore, Schriesheim et al. (2009) examined the individual and team division of the MLQ scale through empirical analysis. The results show that the MLQ scale developed by Bass can be divided into two sub-scales: individual-focused leadership behavior and team-focused leadership behavior. Also consistent with Kark and Shamir's view, the factor analysis in empirical studies indicates that the above classification has stability and a high level of discriminant validity [10]. Wu et al. (2010) also confirmed that individual-focused transformational leadership includes two dimensions of individualized consideration and intellectual stimulation, but they believe that the two-dimensional division of the original team-focused transformational leadership does not fully describe the focus of the team in detail. Therefore, they refine the leadership charm into the leadership charm of behavior and the leadership charm of belonging, together with the inspiration motivation to form a team-focused leadership behavior of three dimensions [11].

Following previous studies, Podaskoff et al. (1990) proposed a transformational leadership of six dimensions that comprise high-performance expectations, fostering the acceptance of group goal, providing individualized support, providing an appropriate model, identifying a vision, and intellectual stimulation, and develops corresponding measurement scales [12]. Wang et al. (2005) based on the scales of scholars such as Podaskoff and tested in the Chinese context. The three dimensions of providing an appropriate model, identifying a vision and high-performance expectations, are used to measure team-level transformational leadership, and for all items, the reference point was set in team level as a whole, but they did not measure and study individual-focused transformational leadership [13]. Later, Wang and Howell (2010) refined the previous research. Based on the Canadian corporations, they proposed individual-focused transformational leadership comprising four dimensions of communicating high expectations, follower development, intellectual stimulation and personal recognition, and team-focused transformational leadership comprising three dimension of emphasizing group identity, communicating a group vision and team-building, 
and the factor analysis shows that the scale has stability and discriminant validity [14]. However, previous hierarchical research and empirical tests on transformational leadership are mostly based on western cultural background, so whether it is applicable to the Chinese context needs further verification. Using Chinese firms sample, Zhang et al. (2013) based on the scales of Podaskoff, explored the structural dimensions of multi-level transformational leadership in China, and they found that team-focused transformational leadership involves four dimensions of identifying and articulating a vision, providing an appropriate model, fostering the acceptance of group goals, and expecting high performance. In addition, the individual-focused transformational leadership includes two dimensions of individual consideration and intellectual inspiration [15]. The above-mentioned transformational leadership hierarchical researches show that Wang and Howell (2010) classify high-performance expectations as individual orientation, while Wang (2005) and Zhang et al. (2013) classify high-performance expectations as team-focused. The diverse classification comes from the different cultural backgrounds, the former research is based on sample of Canadian enterprises and western culture advocates individualism and individual performance, while Wang (2005) and Zhang et al. (2013) are based on Chinese enterprises and Chinese culture is a collectivist culture advocates team performance. So the dimension of high performance expectations should be distributed to the team level rather than the individual level. Therefore, the study of Zhang et al. (2013) is a re-examination of hierarchical transformational leadership in the Chinese context. Cai Yahua et al. (2013) selected the three dimensions of providing an appropriate model, providing team vision and high-performance expectation to measure team-focused transformational leadership based on the research of Wang et al. (2005), and they also set the reference point of the item as the whole team [16]. At the same time, based on the research of Zhang et al. (2013), the two dimensions of intellectual stimulation and individualized care were used to measure individual-focused transformational leadership [17]. Li Guiquan and his colleagues (2014) further confirmed the hierarchical division of transformational leadership structure by Zhang et al. (2013) in the context of China [8] (Table 2).

In recent years, scholars have conducted research on team-focused transformational leadership based on the Chinese context. Xie Jun and Chu Xiaoping's (2016) uses 103 work teams from 22 companies in Guangdong Province and they find that different levels of transformational leadership behavior have different mechanisms for individual creativity/team creativity. In detail, team-focused transformational leadership has a positive impact on team creativity, and structural empowerment plays a fully mediated role between team-focused transformational leadership and team creativity; individual-focused transformational leadership has positive for individual creativity, and the psychological empowerment plays a partially mediated role between individual-focused transformational leadership and individual creativity [18]. Zhao 
Table 2. Individual-focused and team-focused transformational leadership dimensions.

\begin{tabular}{|c|c|c|c|}
\hline & Source of literature & Individual-focused & Team-focused \\
\hline \multirow{3}{*}{$\begin{array}{l}\text { Based on Bass's } \\
\text { research }\end{array}$} & Kark \& Shamir (2002) & $\begin{array}{c}\text { Individualized } \\
\text { Consideration, } \\
\text { Intellectual Stimulation }\end{array}$ & $\begin{array}{c}\text { Charisma, Inspirational } \\
\text { Motivation }\end{array}$ \\
\hline & Schriesheim et al. (2009) & $\begin{array}{c}\text { Individualized } \\
\text { Consideration, } \\
\text { Intellectual Stimulation }\end{array}$ & $\begin{array}{c}\text { Charisma, Inspirational } \\
\text { Motivation }\end{array}$ \\
\hline & Wu et al. (2010) & $\begin{array}{c}\text { Individualized } \\
\text { Consideration, } \\
\text { Intellectual Stimulation }\end{array}$ & $\begin{array}{l}\text { leadership charm of } \\
\text { behavior, leadership } \\
\text { charm of belonging and } \\
\text { inspiration motivation }\end{array}$ \\
\hline \multirow{5}{*}{$\begin{array}{l}\text { Base on Podaskoff's } \\
\text { research }\end{array}$} & Wang et al. (2005) & & $\begin{array}{c}\text { Providing an } \\
\text { appropriate model, } \\
\text { identifying a vision and } \\
\text { high-performance } \\
\text { expectations }\end{array}$ \\
\hline & Wang \& Howel (2010) & $\begin{array}{c}\text { Individualized } \\
\text { Consideration, } \\
\text { Intellectual Stimulation, } \\
\text { Personal identity }\end{array}$ & $\begin{array}{l}\text { Group identity, group } \\
\text { vision, team-building }\end{array}$ \\
\hline & Zhang et al. (2013) & $\begin{array}{c}\text { Individualized } \\
\text { Consideration, } \\
\text { Intellectual Stimulation }\end{array}$ & $\begin{array}{l}\text { Promote teamwork, } \\
\text { clarify visions, role } \\
\text { models, and deliver } \\
\text { high performance } \\
\text { expectations }\end{array}$ \\
\hline & Li, G. Q. et al. (2014) & $\begin{array}{c}\text { Individualized } \\
\text { Consideration, } \\
\text { Intellectual Stimulation }\end{array}$ & $\begin{array}{l}\text { Promote teamwork, } \\
\text { clarify visions, role } \\
\text { models, and deliver } \\
\text { high performance } \\
\text { expectations }\end{array}$ \\
\hline & Cai, Y. H. et al. (2013) & $\begin{array}{c}\text { Individualized } \\
\text { Consideration, } \\
\text { Intellectual Stimulation }\end{array}$ & $\begin{array}{l}\text { Team vision, role } \\
\text { model, high } \\
\text { performance } \\
\text { expectations }\end{array}$ \\
\hline
\end{tabular}

Wei and Li Feng's (2016) pointed out that team-focused transformational leadership positively influences collective identification through relationship identification, which in turn affects team effectiveness [19]. Individual-focused transformational leadership positively influences the relational identification of leadership through the Leadership Member Exchange (LMX), which in turn affects individual effectiveness [17]. Duan Jinyun et al.'s (2017) found that the team's voice atmosphere mediates the positive impact of team-focused transformational leadership on team performance [20]. At the same time, the team innovation atmosphere moderates the relationship between team-focused transformational leadership and team voice atmosphere. While the team innovation atmosphere is high, the relationship between transformational leadership and team voice atmosphere is stronger; the interaction effect between team-focused 
transformational leadership and team innovation atmosphere affects team performance through team voice atmosphere [21]. These scholars all found out that team-focused transformational leadership has a positive impact on team creativity. Xie Jun and Chu Xiaoping's (2016) and other research also found that the positive impact of individual-focused transformational leadership on individual creativity/individual effectiveness. Above-mentioned researches verified previous finding in the Chinese context.

\section{The Mechanism of Team-Focused Transformational Leadership}

The team is a complex system involve various elements, such as internal and external environment, leadership style and task type [22], the complexity of the environment makes the realization of team creativity become challenge. However, as a key role in team management, leadership plays important role in the team.

Previous mostly studies have used leadership as an independent variable. As organizations become more flat, leaders play roles like coordination and communication in the team. Some scholars point out it is necessary to consider leadership as team-level moderator in team research [23]. Research has found that leadership is an important moderator in the team level [24]. Existing research indicates that leader plays an important role in help members leverage internal information resources and motivate members to interact, discuss, integrate and apply different information and perspectives [25]. In the study of team creative relationships, leadership can minimize the negative impact of the social classification process and maximize the positive impact of cognitive diversity [26]. Bang et al. (2015) believe that leaders are able to managing team conflicts effectively. Few scholars have discussed this, what's more, there is rarely empirical research about the role of leadership in the relationship between task conflict and team creativity [27].

The concept of team-focused transformation leadership has re-examined the mechanism of transformational leadership from a new perspective. At the same time, as an important situational elements affecting creativity [23] [28], the relationship between team-focused transformational leadership and creativity is especially concerned.

Team-focused transformational leadership includes inspirational motivation and idealized influence. Under the inspirational motivation, leaders can reduce the negative reactions of team members in the face of diversity by enhance team identity [29]. Under the idealized influence, trust can create a strong sense of cooperation, which drives individuals to search for different ideas and opinions within team and actively integrate these different ideas. Engage in challenging work, take the risk of innovation and explore unusual problem solutions are part of the creative work of team members [23].

Based on the theory of information processing, cognitive diversity can bring a 
large amount of information resources from different perspectives. These messages can cause task conflicts through exchange. The exchange of information between team members depends on the trust of each other. Trust is the confidence of members in team reliability and profession. If the conflict of tasks causes the relationship conflict based on the "mistaken attribution" of the task conflict, then the background of interpersonal relationships-trust, which plays a role of moderator [30]. Team-focused transformational leadership can build trust in team members through idealized influence [31]. Team-focused transformational leadership helps to create a mutually trusting and cooperative work environment within the team. Incentive team members free to express their views and opinions on the content of their work. Which reduce the interpersonal threats caused by mistaken attribution of members and prevent or slow down the transition of task conflicts to relationship conflicts, so that the problem of work can be better solved. Under the inspirational motivation, team-focused transformational leadership emphasis on team goals and give team members confidence, allows team members to know how to realize team goals, then reduce cognitive load through eliminate unsatisfactory ideas and discussions clearly when discussing in a team. Team-focused transformational leadership emphasizes the team's identity and team goals to enhance the motivation of subordinates to complete their work. Besides, team-focused transformational leadership can increases interaction between team members, team members become more familiar with each other and understands each other, furthermore, enhances trust between team members as well as their leadership [32]. When team members have a clear understanding of team goals and have highly trust with each other, they are not need worry about face, so they can better listen to each other's views and spare no effort to contribute their own ideas and opinions. There is no doubt that team members can integrate different information within the team and provide a strong guarantee for team members to achieve team goals.

Team-focused transformational leadership focuses on the team as a whole, makes subordinates aware of the meaning or value of the work and feel pleasure. Driven by intrinsic motivation, team members are more focused on how to accomplish tasks creatively and improve their work efficiency. Team-focused transformational leadership plays an active role in conflicts of tasks by strengthen the identity, trust, and motivation of team members, team members are more willing to communicate, share, and collaborate with others, thus the team more likely acquire new ideas to be more creative. Not only that, Zhang et al. (2013)'s empirical result also indicates that team-focused transformational leadership has a significant positive impact on team creativity [17].

\section{Conclusion}

This paper classifies the concept of transformational leadership and comparison

of transformational leadership and other types of leadership, then classifies the 
concept and related research of team-focused transformational leadership and individual-focused transformational leadership. The proposal of differentiated transformational leadership re-examined the traditional transformational leadership theory from a new perspective. Individual-focused transformational leadership pays attention to individual employees and cares about their self-development. Team-focused transformational leadership focuses on the team as a whole and pays more attention to the team's interests. They consider problems from the team's point of view, and strengthen team building through team trust and emphasis on team goals, so that team members can better accomplish organizational goals. Team-focused transformational leadership and individual-focused transformational leadership work at different levels. Research shows that team-focused transformational leadership focuses on the team level and has a positive impact on outcome variables such as team creativity.

\section{Contribution of Research}

Previous research on the concept of transformational leadership is unclear. It is found that transformational leadership can be divided into team level and individual level. The mechanism of team-focused transformational leadership and individual-focused transformational leadership is different. Therefore, in enterprise management, it is necessary to provide leadership-related training courses for managers. Leaders should demonstrate different leadership behaviors for different periods of team development and different individual employees. At the team level, strengthen team building through articulate the vision of the organization clearly and play role models to team members. At the individual level, employees should be given different guidance to be influenced and motivated to achieve the team goal.

\section{Limitation and Future Research}

First, from the structural dimension, there is still a huge difference in the division of the team-focused transformational leadership dimension, although some scholars analyze one of the reasons is the different research contexts, such as high performance expectations belongs to team-focused transformational leadership in the Chinese context, but it belongs to individual-focused transformational leadership in the Canadian context. Future research should delve into the impact of different cultural backgrounds on the team-focused transformational leadership structure dimension.

Secondly, in the theoretical research, the introduction of team-focused transformational leadership has promoted the new development of transformational leadership theory to a certain degree, but the domestic team-focused transformational leadership is still in its infancy, relevant research focuses on team creativity and innovation performance [16] [19] [20]. However, leadership usually plays the role of coordination and communication within team. It is necessary to expand the research on team-focused transformational leadership in the future. 
In particular, the mechanism of team-focused transformational leadership as a moderator needs more in-depth exploration.

\section{Conflicts of Interest}

The author declares no conflicts of interest regarding the publication of this paper.

\section{References}

[1] Longshore, J.M. and Bass, B.M. (1985) Leadership and Performance beyond Expectations. Academy of Management Review, 12, 756.

[2] Avolio, B.J., Bass, B.M. and Dong, I.J. (1999) Re-Examining the Components of Transformational and Transactional Leadership Using the Multifactor Leadership. Journal of Occupational \& Organizational Psychology, 72, 441-462. https://doi.org/10.1348/096317999166789

[3] Wei, F., Yuan, X. and Di, Y. (2009) Multi-Level Research on the Influence of Transactional Leadership, Team Empowerment Atmosphere and Psychological Empowerment on Subordinates' Innovation Performance. Management World, No. $4,135-142$.

[4] Pless, N.M. and Maak, T. (2012) Responsible Leadership. Routledge, Abingdon-on-Thames.

[5] Gupta, V., Macmillan, I.C. and Surie, G. (2004) Entrepreneurial Leadership: Developing and Measuring a Cross-Cultural Construct. Journal of Business Venturing, 19, 241-260. https://doi.org/10.1016/S0883-9026(03)00040-5

[6] van Knippenberg, D. and Sitkin, S.B. (2013)A Critical Assessment of Charismatic-Transformational Leadership Research: Back to the Drawing Board? Academy of Management Annals, 7, 1-60. https://doi.org/10.5465/19416520.2013.759433

[7] Kark, R. and Shamir, B. (2002) The Dual Effect of Transformational Leadership: Priming Relational and Collective Selves and Further Effects on Followers. Emerald Group Publishing Limited, Bingley.

[8] Podsakoff, P.M., Mackenzie, S.B., Moorman, R.H., et al. (1990) Transformational Leader Behaviors and Their Effects on Followers' Trust in Leader, Satisfaction, and Organizational Citizenship Behaviors. Leadership Quarterly, 1, 107-142. https://doi.org/10.1016/1048-9843(90)90009-7

[9] Wu, J.B., Tsui, A.S. and Kinicki, A.J. (2010) Consequences of Differentiated Leadership in Groups. Academy of Management Journal, 53, 90-106. https://doi.org/10.5465/amj.2010.48037079

[10] Wang, X. and Howell, J.M. (2010) Exploring the Dual-Level Effects of Transformational Leadership on Followers. Journal of Applied Psychology, 95, 1134-1144. https://doi.org/10.1037/a0020754

[11] Yammarino, F.J. and Bass, B.M. (1990) Transformational Leadership and Multiple Levels of Analysis. Human Relations, 43, 975-995. https://doi.org/10.1177/001872679004301003

[12] Dong, Y., Bartol, K.M., Zhang, Z.X., et al. (2017) Enhancing Employee Creativity via Individual Skill Development and Team Knowledge Sharing: Influences of Dual-Focused Transformational Leadership. Journal of Organizational Behavior, 38, 439-458. https://doi.org/10.1002/job.2134

[13] Li, G.Q. and Liu, H.X. (2014) Research on the Cross-Level Effect of Differentiated 
Transformational Leadership on Knowledge Sharing. Soft Science, No. 12, 116-119.

[14] Li, G., Shang, Y., Liu, H., et al. (2014) Differentiated Transformational Leadership and Knowledge Sharing: A Cross-Level Investigation. European Management Journal, 32, 554-563. https://doi.org/10.1016/j.emj.2013.10.004

[15] Schriesheim, C.A., Wu, J.B. and Scandura, T.A. (2009) Erratum to a Meso Measure? Examination of the Levels of Analysis of the Multifactor Leadership Questionnaire (MLQ). The Leadership Quarterly, 21, 204. https://doi.org/10.1016/j.leaqua.2009.10.016

[16] Cai, Y.H., Jia, L.D. and You, S.Y. (2013) The Influence of Differentiated Transformational Leadership on Knowledge Sharing and Team Creativity: A Social Network Explanation. Acta Psychologica Sinica, 5, 585-598. https://doi.org/10.3724/SP.J.1041.2013.00585

[17] Zhang, X., Li, N., Ullrich, J., et al. (2013) Getting Everyone on Board the Effect of Differentiated Transformational Leadership by CEOs on Top Management Team Effectiveness and Leader-Rated Firm Performance. Journal of Management, 41, 1898-1933. https://doi.org/10.1177/0149206312471387

[18] Wang, H., et al. (2005) Leader-Member Exchange as a Mediator of the Relationship between Transformational Leadership and Followers' Performance and Organizational Citizenship Behavior. Academy of Management Journal, 48, 420-432. https://doi.org/10.5465/amj.2005.17407908

[19] Zhao, Q. and Li, F. (2016) Team Leadership and Team Effectiveness: A Multilevel Study through the Lens of Social Identity Theory. Advances in Psychological Science, No. 11, 1677-1689.

[20] Duan, J.Y., Xiao, J.Y. and Xia, X.T. (2017) Transformational Leadership, Group Voice Climate and Group Performance: The Moderating Effect of Innovation Climate. Science Research Management, No. 4, 76-83.

[21] Xie, J. and Chu, X.P. (2016) The Influence of Multi-Level Focused Transformational Leadership on Individual and Team Creativity: The Mediating Role of Empowerment. Journal of Industrial Engineering and Engineering Management, 30, 161-167.

[22] Yuan, L., Liu, P. and Tu, Y.H. (2016) The Research on the Relationship between Task Conflict and Team Performance under the Mediating Effects of Information Elaboration in Knowledge Teams. Science \& Technology Progress and Policy, No. 13, 135-140.

[23] Kim, T.Y., Shin, S.J., Lee, J.Y., et al. (2012) Cognitive Team Diversity and Individual Team Member Creativity: A Cross-Level Interaction. Academy of Management Journal, 55, 197-212. https://doi.org/10.5465/amj.2010.0270

[24] David, D.C. and Daan, V.K. (2004) Leader Self-Sacrifice and Leadership Effectiveness: The Moderating Role of Leader Self-Confidence. Organizational Behavior and Human Decision Processes, 95, 140-155.

https://doi.org/10.1016/j.obhdp.2004.04.002

[25] Resick, C.J., Murase, T., Randall, K.R., et al. (2014) Information Elaboration and Team Performance: Examining the Psychological Origins and Environmental Contingencies. Organizational Behavior \& Human Decision Processes, 124, 165-176. https://doi.org/10.1016/j.obhdp.2014.03.005

[26] Kearney, E. and Gebert, D. (2009) Managing Diversity and Enhancing Team Outcomes: The Promise of Transformational Leadership. Journal of Applied Psychology, 94, 77-89. https://doi.org/10.1037/a0013077

[27] Bang, H. and Park, J.G. (2015) The Double-Edged Sword of Task Conflict: Its Impact on Team Performance. Social Behavior \& Personality: An International Jour- 
nal, 43, 715-728. https://doi.org/10.2224/sbp.2015.43.5.715

[28] Shin, S.J. and Zhou, J. (2007) When Is Educational Specialization Heterogeneity Related to Creativity in Research and Development Teams? Transformational Leadership as a Moderator. Journal of Applied Psychology, 92, 1709-1721. https://doi.org/10.1037/0021-9010.92.6.1709

[29] Yorges, S.L., Weiss, H.M. and Strickland, O.J. (1999) The Effect of Leader Outcomes on Influence, Attributions, and Perceptions of Charisma. Journal of Applied Psychology, 84, 428-436. https://doi.org/10.1037/0021-9010.84.3.428

[30] Dai, P.H. and Fan, L.L. (2014) The Effect of Team Task Conflict on Decision-Making Quality and the Role of Trust in the Effecting Process. Forecasting, No. 6, 31-36.

[31] Gillespie, N.A. and Mann, L. (2004) Transformational Leadership and Shared Values: The Building Blocks of Trust. Journal of Managerial Psychology, 19, 588-607. https://doi.org/10.1108/02683940410551507

[32] Braun, S., Peus, C., Weisweiler, S., et al. (2013) Transformational Leadership, Job Satisfaction, and Team Performance: A Multilevel Mediation Model of Trust. Leadership Quarterly, 24, 270-283. https://doi.org/10.1016/j.leaqua.2012.11.006 